\title{
Effect of Edible Coatings and Storage Temperatures on Maintenance of Aril Quality and Microbial Population of Pomegranate cv. Bhagwa Packed in Clamshells
}

\author{
M. Viswanath*, B. Srinivasulu, K. Swarajya Lakshmi, K. Gopal and M. Balakrishna \\ Horticultural College and Research Institute, Anantharaju Peta, Dr. YSR Horticultural \\ University, Andhra Pradesh, India \\ *Corresponding author
}

\section{A B S T R A C T}

\begin{tabular}{|l|}
\hline Ke y w o r d s \\
$\begin{array}{l}\text { Arils of pomegranate, } \\
\text { Chitosan, Honey, Aloe } \\
\text { vera gel and Storage } \\
\text { temperatures }\end{array}$ \\
\hline Article Info \\
\hline $\begin{array}{l}\text { Accepted: } \\
\text { 16 December } 2017 \\
\text { Available Online: } \\
\text { 10 January } 2018\end{array}$ \\
\hline
\end{tabular}

\section{Keywords}

Arils of pomegranate, , Honey, Aloe temperatures

\section{Introduction}

Pomegranate (Punica granatum L.) which is regarded as the 'elixir of life' is a rich source of minerals, vitamins and nutrients. It belongs to the family Punicaceae and originated from Iran. Pomegranate fruits are large round berries called as balusta and aril is the edible material. It has seen a remarkable increase in the commercial farming, due to its potential health benefits such as, its high anti-oxidant, anti-mutagenic, anti-hypertension activities and the ability to reduce liver injury (Violeta Lopez-Rubira, 2005). Pomegranate fruits are

\begin{abstract}
A major challenge facing the fresh-cut industry is maintaining and preserving the quality of minimally processed or fresh-cut produce. A low temperature regime, although insufficient, has been the main method of overcoming this challenge so far. Thus, methods preserving the quality and extending the shelf life of minimally processed or fresh-cut produce are needed. This paper seeks to propose that edible coatings could be used to preserve the fresh-like quality of minimally processed pomegranate arils and extend their shelf life. Studies were conducted on three different edible coatings chitosan (1\%), aloe vera gel $(100 \%)$ and honey $(10 \%)$. The coated arils were packed in clamshells and stored at different temperatures $4{ }^{\circ} \mathrm{C}, 7^{\circ} \mathrm{C}$ and room temperature $\left(26^{\circ} \mathrm{C}\right)$. Findings of this study demonstrate the potential of using chitosan (1\%) as edible coating has found promising to maintain aril quality with inhibited microbial growth on the surface of arils stored at cold temperature $4 \pm 1^{\circ} \mathrm{C}$ during 20 days of storage.
\end{abstract}

consumed fresh or processed as juice, jellies and syrup for industrial production. In recent years, minimally processed ready-to-eat pomegranate arils have become popular due to their convenience and high value. Minimal processing which involves light processing such as peeling is of great importance for adding convenience to the consumers. The processing of externally damaged pomegranates could be an excellent way to obtain a commercial profit from discarded pomegranates that are unacceptable for fresh marketing and consumption. A commercialization of minimally processed and 
"ready-to-eat" fresh arils is the good alternative to later demands of newly evolving health conscious consumer class which also expects convenience. Fresh-cut products are particularly susceptible to microbial growth owing to the removal of plant protective tissue and the release of cellular fluids from cutting (Heard, 2002), which results in shelf-life reduction and decrease in bioactive compounds concentration. To extend the shelf life of fresh-cut produce, previous research has focused on the use of refrigeration, antibrowning agents, chemical dipping, and controlled atmospheres. Recent advances include the use of organic edible coatings like chitosan, aloe vera gel, honey etc.

Chitosan, a high molecular weight cationic polysaccharide, produced by the deacetylation of chitin, is widely used in postharvest trials because of its excellent film forming and anti-fungal, bio-safe and biochemical properties (Lin et al., 2008). It activates several defence processes in the host tissue, acts as a water-binding agent and inhibits various enzymes.

The antifungal and antimicrobial activities of chitosan in fresh fruits and vegetables are believed to originate from its polycationic nature. The bactericidal activity of chitosan is caused by the electrostatic interaction between $\mathrm{NH}+3$ groups of chitosan and phosphoryl groups of the phospholipid components of the cell membrane (Liu et al., 2001). Interestingly, the antifungal activity of Aloe vera gel from several species has been correlated with the content of aloin, one of the major phenolic compounds of Aloe leaves.

Honey, an organic substance which is fairly acidic, mainly composed of fructose (about $38-55 \%$ ) and glucose (about 31\%) is widely used in food processing industries due to their low water content which prevents the growth of micro-organisms and extends their shelf life with no off flavour (Eman et al., 2015). Temperature is one of the main factors that affect the physiological properties of fruit; the storage temperature recommended for pomegranate varies from 0 to $10^{\circ} \mathrm{C}$ with a storage life ranging from 2 weeks to 7 months depending on the cultivar. Recently, more attention has been paid to the potential use of packaging material in food industries due to their eco-friendly and biodegradable properties. Clamshell packaging provides structural support for convenient storage and easy handling of the produce also play an important role in maintaining nutritional and microbial quality of fresh or fresh cut produce (Caleb et al., 2013).

The present study was performed to determine if edible coatings and storage temperatures could be an alternate way to preserve the minimally processed pomegranate arils, with reduced microbial population and extend the shelf life.

\section{Materials and Methods}

Fruits of pomegranate variety, Bhagwa used in the experiment were obtained from AICRP centre on Arid Zone fruits, Horticulture Research Station, Rekulakunta, Ananthapuramu district, Andhra Pradesh, India. Well-developed fruits at optimum stage of maturity, free from pest and disease attack were harvested from the field and brought to the laboratory.

The arils from fruits were extracted manually after splitting the fruits with the help of sterilized knife. The entire process of aril extraction and packing was done under hygienic conditions. Edible coatings viz., chitosan (1\%), Aloe vera gel (100\%) and honey $(10 \%)$ were used for treating the arils. The treated arils packed in clamshells were kept at $4 \pm 1^{\circ} \mathrm{C}, 7 \pm 1^{\circ} \mathrm{C}$ and room temperature $\left(26-29^{\circ} \mathrm{C}\right)$. 


\section{Preparation of edible coating}

\section{Chitosan (1\%)}

Chitosan with 90\% de-acetylation and a molecular weight of $360 \mathrm{kDa}$ was prepared at $1 \%(\mathrm{w} / \mathrm{v})$ concentration in an aqueous solution of acetic acid $(0.5 \% \mathrm{v} / \mathrm{v})$. The solution was warmed to $45^{\circ} \mathrm{C}$ and stirred for complete dissolution of chitosan, adjusting its $\mathrm{pH}$ to 5.2 with $\mathrm{NaOH}$. After cooling at $20^{\circ} \mathrm{C}$, the arils were dipped in the chitosan solution for 60 seconds to generate a uniform film.

\section{Aloe vera $(\mathbf{1 0 0 \%})$}

Matured leaves from Aloe vera plant were harvested and washed with a mild chlorine solution of $25 \%$. Aloe vera gel matrix was then separated from the outer cortex of leave and this colourless hydro parenchyma was ground in a blender. The resulting mixture was filtered to remove the fibres. The gel matrix was pasteurized at $70^{\circ} \mathrm{C}$ for $45 \mathrm{~min}$. For stabilization, the gel was cooled immediately to an ambient temperature.

\section{Honey (10\%)}

Honey solution $10 \mathrm{~g}$ was dissolved in one litre of warm water to get honey (10\%) solution.

\section{Microbial count (CFU)}

For microbial count estimation, 28g of Nutrient Agar (NA) was suspended in a 1000 $\mathrm{ml}$ of distilled water in one beaker and $39 \mathrm{~g}$ of Potato Dextrose Agar (PDA) in $1000 \mathrm{ml}$ of distilled water in another beaker and both of them heated to boiling in order to dissolve the medium completely. After that, sterilization was done by autoclaving at $15 \mathrm{lbs}$ pressure $\left(121^{\circ} \mathrm{C}\right)$ for 15 minutes. Mixed media was poured in petriplates in laminar airflow chamber. The test tubes in test tube stand were added with $9 \mathrm{ml}$ distilled water in each test tube. After that, sterilize the test tubes at 15 psi and $121^{\circ} \mathrm{C}$ in autoclave. Adding the $1 \mathrm{~g}$ of arils in one test tube and labelled as 10. From this test tube $1 \mathrm{ml}$ of sample was taken in another test tube and labelled as $10^{-1}$. This step is repeated upto $10^{-3}$. $100 \mathrm{ml}$ micro litre samples were taken and added aseptically with the help of micro pipette in three different NGA and PDA plates and spread it with the help of spreader. These plates were kept in BOD incubator (PDA plates at $30^{\circ}$ and NGA plates at $25^{\circ} \mathrm{C}$ ) for incubation. Count for $\mathrm{CFU}$ done after $48 \mathrm{hrs}$.

\section{Sensory evaluation}

The stored arils of pomegranate were examined for their sensory qualities by assessing the colour, flavour, texture and overall acceptability. Sensory evaluation was carried out by a panel of 5 judges and the rating was done with score on 9 point Hedonic scale (Amerine et al., 1965) as given below.

\section{Results and Discussion}

\section{Microbial count (CFU)}

Previous studies showed that chitosan could directly inhibit spore germination, germ tube elongation and mycelia growth of many phytopathogens while decreasing decay incidence and prolonging the storage time of fruits. The mechanism by which chitosan affects the growth of pathogens may be related to its ability to form a film on the fruit surface, which acts as a mechanical barrier to protect the aril from pathogen infection, contributing to decreased decay during storage. Furthermore, low-molecular-weight chitosan exhibited higher activity against various fungi. Coating fruits and vegetables with chitosan also provides a type of active package, as preservatives are released from the film deposited on the surface of the food, and these inhibit fungal growth. 
In the present study chitosan coating significantly reduced the growth of bacteria and fungi on pomegranate arils during cold storage (Table 1$)$ on $4^{\text {th }}(2.42), 8^{\text {th }}(3.45), 12^{\text {th }}$ (1.46) $16^{\text {th }}(2.73)$ and $20^{\text {th }}$ (3.93) day of storage, lowest microbial count (CFU) was observed in $\mathrm{C}_{1}$ (1\% chitosan) whereas, the highest microbial count (CFU) was recorded in $\mathrm{C}_{4}$ control $(3.44)$ on $4^{\text {th }}$ day itself resulting in spoilage of arils.

The present findings were similar to the observations made by Chien et al., (2007) in citrus fruit. According to him, chitosan coating markedly inhibited the growth of $P$. digitatum, $P$. italicum, B. Lecanidion, and $B$. Cinerea in citrus fruit during storage. El-Ghaouth et al., (1992) also reported that chitosan coated tomatoes were prevented by attack of Penicillium spp., Aspergillus spp., Rhizopus stolonifer and Botrytis cinerea. Chitosan coating on the sliced mango effectively inhibited the growth of microorganisms (Chien et al., 2007).

Moreover, Chitosan has itself ability to control some fungal diseases, which deteriorate fruit quality during storage (Muzzarelli and Rocchetti, 1985).

With respect to storage temperatures, no microbial growth in arils was observed in $T_{1}$ $\left(4 \pm 1^{\circ} \mathrm{C}\right)$ and $\mathrm{T}_{2}\left(7 \pm 1^{\circ} \mathrm{C}\right)$ upto $8^{\text {th }}$ day of storage. Whereas, $\mathrm{T}_{3}$ (room temperature) recorded the microbial growth of 8.04 and 10.39 (CFU) on $4^{\text {th }}$ and $8^{\text {th }}$ day of storage (Fig. 1). The microbial count (CFU) recorded in $\mathrm{T}_{1}$ arils $\left(4 \pm 1^{\circ} \mathrm{C}\right)$ on $12^{\text {th }}, 16^{\text {th }}$ and $20^{\text {th }}$ day of storage was $1.58,3.08$ and 3.78 , respectively.

Gill et al., (1996) reported that the risk of microbial proliferation is reduced when pomegranate arils were stored at lower temperatures. The interaction between edible coatings and storage temperatures was found significant with respect to microbial count
$(\mathrm{CFU})$ in arils. $\mathrm{C}_{1} \mathrm{~T}_{1}\left(1 \%\right.$ chitosan and $\left.4 \pm 1^{\circ} \mathrm{C}\right)$ recorded lowest microbial count (CFU) (1.20) whereas highest (10.32) was recorded in $\mathrm{C}_{4} \mathrm{~T}_{3}$ (control and room temperature) on $4^{\text {th }}$ day of storage, respectively.

\section{Taste of arils}

The best organoleptic score $(7.93,7.45,7.47$, 6.70 and 6.50) for arils taste was recorded in $\mathrm{C}_{1}$ (1\% chitosan) which was on par with $\mathrm{C}_{3}$ (10\% honey) and $\mathrm{C}_{2}(100 \%$ aloe vera gel) on $4^{\text {th }}, 8^{\text {th }}, 12^{\text {th }}, 16^{\text {th }}$ and $20^{\text {th }}$ day of storage, respectively. There was a reducing trend in organoleptic score of taste of arils during the period of storage and this might be due to fluctuations in acids, $\mathrm{pH}$ and sugar/acid ratio as reported by Malundo et al., (1997) in mango. The small variation in taste scores of treated pomegranate arils was for chitosan coating, which maintained taste and retained the quality until 20 days of storage (Kays et al., 1997). Munoz et al., (2006) stated that, the influence of the chitosan on strawberries stored at $20^{\circ} \mathrm{C}$ for 4 days showed better maintenance of eating quality. The best organoleptic score for aril taste was recorded in $\mathrm{C}_{1}(1 \%$ chitosan) and the least score was recorded in $\mathrm{C}_{4}$ (control).

Among temperatures, $\mathrm{T}_{1}\left(4 \pm 1^{\circ} \mathrm{C}\right)$ recorded the maximum organoleptic score $(8.78,8.23,7.42$, 6.66 and 6.71 ) for aril taste on $4^{\text {th }}, 8^{\text {th }}, 12^{\text {th }}$, $16^{\text {th }}$ and $20^{\text {th }}$ day of storage, respectively. The low temperature maintained the aril quality which influenced the aril taste (Fig. 3). Jiang and $\mathrm{Li},(2001)$ reported that chitosan treated long an fruit had good eating quality even after 30 days of storage at $2^{\circ} \mathrm{C}$.

The interaction effect between coatings and temperatures revealed that the organoleptic score for taste of arils was maximum in $\mathrm{C}_{1} \mathrm{~T}_{1}$ $\left(1 \%\right.$ chitosan and $\left.4 \pm 1^{\circ} \mathrm{C}\right)$ and the minimum organoleptic score for this trait was recorded in $\mathrm{C}_{4} \mathrm{~T}_{3}$ (control and room temperature). 
Table.1 Effect of different edible coatings and storage temperatures on microbial count (CFU) of arils of pomegranate cv. Bhagwa

\begin{tabular}{|c|c|c|c|c|c|c|c|c|c|c|c|c|c|c|c|c|c|c|c|c|c|c|c|c|c|c|c|}
\hline \multicolumn{28}{|c|}{ Microbial count (CFU) } \\
\hline \multicolumn{28}{|c|}{ Storage period (days) } \\
\hline & 0 & \multicolumn{6}{|c|}{4} & \multicolumn{5}{|c|}{8} & \multicolumn{5}{|c|}{12} & \multicolumn{5}{|c|}{16} & \multicolumn{5}{|c|}{20} \\
\hline & & $\mathrm{C}_{1}$ & & $\mathrm{C}_{2}$ & $\mathrm{C}_{3}$ & $\mathrm{C}_{4}$ & Mean & $\mathrm{C}_{1}$ & $\mathrm{C}_{2}$ & $\mathrm{C}_{3}$ & $\mathrm{C}_{4}$ & Mean & $\mathrm{C}_{1}$ & $\mathrm{C}_{2}$ & $\mathrm{C}_{3}$ & $\mathrm{C}_{4}$ & Mean & $\mathrm{C}_{1}$ & $\mathbf{C}_{2}$ & $\mathrm{C}_{3}$ & $\mathrm{C}_{4}$ & Mean & $\mathrm{C}_{1}$ & $\mathbf{C}_{2}$ & $\mathrm{C}_{3}$ & $\mathrm{C}_{4}$ & Mean \\
\hline $\mathbf{T}_{1}$ & 0.0 & $\begin{array}{c}0.0 \\
(0.71)\end{array}$ & & $\begin{array}{l}0.0 \\
0.71)\end{array}$ & $\begin{array}{c}0.0 \\
(0.71)\end{array}$ & $\begin{array}{c}0.0 \\
(0.71)\end{array}$ & $\begin{array}{c}0.0 \\
(0.71)\end{array}$ & $\begin{array}{c}0.0 \\
(0.71)\end{array}$ & $\begin{array}{c}0.0 \\
(0.71)\end{array}$ & $\begin{array}{c}0.0 \\
(0.71)\end{array}$ & $\begin{array}{c}0.0 \\
(0.71)\end{array}$ & $\begin{array}{c}0.0 \\
(0.71)\end{array}$ & $\begin{array}{c}1.20 \\
(1.30)\end{array}$ & $\begin{array}{c}1.23 \\
(1.32)\end{array}$ & $\begin{array}{c}1.28 \\
(1.33)\end{array}$ & $\begin{array}{c}2.63 \\
(1.77)\end{array}$ & $\begin{array}{c}1.58 \\
(1.44)\end{array}$ & $\begin{array}{c}2.33 \\
(1.68)\end{array}$ & $\begin{array}{c}2.36 \\
(1.69)\end{array}$ & $\begin{array}{c}2.38 \\
(1.70)\end{array}$ & $\begin{array}{c}5.26 \\
(2.40)\end{array}$ & $\begin{array}{c}3.08 \\
(1.89)\end{array}$ & $\begin{array}{c}3.75 \\
(2.06)\end{array}$ & $\begin{array}{c}3.78 \\
(2.07)\end{array}$ & $\begin{array}{c}3.80 \\
(2.07)\end{array}$ & * & $\begin{array}{c}3.78 \\
(2.07)\end{array}$ \\
\hline $\mathbf{T}_{2}$ & 0.0 & $\begin{array}{c}0.0 \\
(0.71)\end{array}$ & & $\begin{array}{l}0.0 \\
0.71)\end{array}$ & $\begin{array}{c}0.0 \\
(0.71)\end{array}$ & $\begin{array}{c}0.0 \\
(0.71)\end{array}$ & $\begin{array}{c}0.0 \\
(0.71)\end{array}$ & $\begin{array}{c}0.0 \\
(0.71)\end{array}$ & $\begin{array}{c}0.0 \\
(0.71)\end{array}$ & $\begin{array}{c}0.0 \\
(0.71)\end{array}$ & $\begin{array}{c}0.0 \\
(0.71)\end{array}$ & $\begin{array}{c}0.0 \\
(0.71)\end{array}$ & $\begin{array}{c}1.73 \\
(1.49)\end{array}$ & $\begin{array}{c}1.76 \\
(1.50)\end{array}$ & $\begin{array}{c}1.79 \\
(1.51)\end{array}$ & $\begin{array}{c}3.72 \\
(2.05)\end{array}$ & $\begin{array}{c}2.25 \\
(1.66)\end{array}$ & $\begin{array}{c}3.13 \\
(1.91)\end{array}$ & $\begin{array}{c}3.17 \\
(1.92)\end{array}$ & $\begin{array}{c}3.20 \\
(1.92)\end{array}$ & * & $\begin{array}{c}3.17 \\
(1.92)\end{array}$ & $\begin{array}{c}4.11 \\
(2.15)\end{array}$ & $\begin{array}{l}4.16 \\
(2.16)\end{array}$ & $\begin{array}{c}4.18 \\
(2.16)\end{array}$ & * & $\begin{array}{c}4.15 \\
(2.16)\end{array}$ \\
\hline$T_{3}$ & 0.0 & $\begin{array}{c}7.26 \\
(2.79)\end{array}$ & & $\begin{array}{l}7.28 \\
2.79)\end{array}$ & $\begin{array}{c}7.30 \\
(2.79)\end{array}$ & $\begin{array}{l}10.32 \\
(3.29)\end{array}$ & $\begin{array}{c}8.04 \\
(2.92)\end{array}$ & $\begin{array}{l}10.36 \\
(3.30)\end{array}$ & $\begin{array}{l}10.38 \\
(3.30)\end{array}$ & $\begin{array}{l}10.42 \\
(3.30)\end{array}$ & $*$ & $\begin{array}{l}10.39 \\
(3.30)\end{array}$ & $*$ & $*$ & $*$ & $*$ & $*$ & $*$ & $*$ & $*$ & $*$ & $*$ & $*$ & $*$ & $*$ & * & $*$ \\
\hline Mean & 0.0 & $\begin{array}{c}2.42 \\
(1.71)\end{array}$ & & $\begin{array}{l}2.43 \\
1.71)\end{array}$ & $\begin{array}{c}2.43 \\
(1.71)\end{array}$ & $\begin{array}{c}3.44 \\
(1.98)\end{array}$ & & $\begin{array}{c}3.45 \\
(1.99)\end{array}$ & $\begin{array}{c}3.46 \\
(1.99)\end{array}$ & $\begin{array}{c}3.47 \\
(1.99)\end{array}$ & $\begin{array}{c}0.0 \\
(0.71)\end{array}$ & & $\begin{array}{c}1.46 \\
(1.40)\end{array}$ & $\begin{array}{c}1.49 \\
(1.41)\end{array}$ & $\begin{array}{c}1.53 \\
(1.42)\end{array}$ & $\begin{array}{c}3.17 \\
(1.92)\end{array}$ & & $\begin{array}{c}2.73 \\
(1.80)\end{array}$ & $\begin{array}{c}2.76 \\
(1.81)\end{array}$ & $\begin{array}{c}2.79 \\
(1.81)\end{array}$ & $\begin{array}{c}5.26 \\
(2.40)\end{array}$ & & $\begin{array}{c}3.93 \\
(2.10)\end{array}$ & $\begin{array}{c}3.97 \\
(2.11)\end{array}$ & $\begin{array}{c}3.99 \\
(2.12)\end{array}$ & * & \\
\hline & istics & \multicolumn{3}{|c|}{ SE.m \pm} & \multicolumn{3}{|c|}{ CD @ P=0.05 } & \multicolumn{2}{|c|}{ SE.m \pm} & \multicolumn{3}{|c|}{$\mathbf{C D} @ \mathbf{P}=\mathbf{0 . 0 5}$} & \multicolumn{2}{|c|}{ SE.m \pm} & \multicolumn{3}{|c|}{ CD @ $P=0.05$} & \multicolumn{2}{|c|}{ SE.m \pm} & \multicolumn{3}{|c|}{ CD @ P=0.05 } & \multicolumn{2}{|c|}{ SE.m \pm} & \multicolumn{3}{|c|}{$C D @ P=0.05$} \\
\hline & C & \multirow{2}{*}{\multicolumn{3}{|c|}{0.03}} & \multirow{2}{*}{\multicolumn{3}{|c|}{$\begin{array}{l}0.10 \\
0.09\end{array}$}} & \multirow{2}{*}{\multicolumn{2}{|c|}{0.04}} & \multirow{2}{*}{\multicolumn{3}{|c|}{0.13}} & \multirow{2}{*}{\multicolumn{2}{|c|}{0.02}} & & 0.06 & & 0. & & & 0.08 & & & & & 0.08 & \\
\hline & $T$ & & & & & & & & & & & & & & & 0.05 & & 0. & & & 0.07 & & & & & 0.07 & \\
\hline & $\overline{\mathrm{C} \times \mathrm{T}}$ & & .06 & & & 0.18 & & 0. & & & 0.23 & & & & & 0.10 & & 0. & & & 0.14 & & & & & 0.14 & \\
\hline & & Note & 11 & zures & n pare & athese & re sq & re ro & $\operatorname{tran}$ & forme & ed values & & & & & & & & & & & & & & & & \\
\hline & & $\mathrm{C}_{1}$ & $:$ & Chi & $\operatorname{tosan}($ & $\%)$ & & & $\mathrm{T}_{1}$ & $:$ & $\pm 1^{0} \mathrm{C}$ & & & & & & $*$ & Decayed & arils & & & & & & & & \\
\hline & & $\mathrm{C}_{2}$ & : & Alo & vera $g$ & $1(100$ & & & $\mathrm{T}_{2}$ & : & $\pm 1^{0} \mathrm{C}$ & & & & & & & & & & & & & & & & \\
\hline & & $\mathrm{C}_{3}$ & : & Hor & ey $(10 \%$ & & & & $\mathrm{T}_{3}$ & $:$ & Room tem & erature & $(26-29$ & & & & & & & & & & & & & & \\
\hline & & $\mathrm{C}_{4}$ & : & Con & trol $(\mathrm{Ur}$ & -treate & & & & & & & & & & & & & & & & & & & & & \\
\hline
\end{tabular}

Table.2 Effect of different edible coatings and storage temperatures on overall acceptability of arils of pomegranate cv. Bhagwa

\begin{tabular}{|c|c|c|c|c|c|c|c|c|c|c|c|c|c|c|c|c|c|c|c|c|c|c|c|c|c|c|c|}
\hline \multicolumn{28}{|c|}{ Overall acceptability of arils (organoleptic score) } \\
\hline \multicolumn{28}{|c|}{ Storage period (days) } \\
\hline & $\mathbf{0}$ & \multicolumn{6}{|c|}{4} & \multicolumn{5}{|c|}{8} & \multicolumn{5}{|c|}{12} & \multicolumn{5}{|c|}{16} & \multicolumn{5}{|c|}{20} \\
\hline & & & $\mathbf{C}_{1}$ & $\mathbf{C}_{2}$ & $\mathbf{C}_{3}$ & $\mathbf{C}_{4}$ & Mean & $\mathbf{C}_{1}$ & $\mathbf{C}_{2}$ & $\mathbf{C}_{3}$ & $\mathbf{C}_{4}$ & Mean & $\mathbf{C}_{1}$ & $\mathbf{C}_{2}$ & $\mathbf{C}_{3}$ & $\mathbf{C}_{4}$ & Mean & $\mathbf{C}_{1}$ & $\mathbf{C}_{2}$ & $\mathbf{C}_{3}$ & $\mathbf{C}_{4}$ & Mean & $\mathbf{C}_{1}$ & $\mathbf{C}_{2}$ & $\mathbf{C}_{3}$ & $\mathbf{C}_{4}$ & Mean \\
\hline $\mathrm{T}_{1}$ & 8.73 & & 8.83 & 8.76 & 8.80 & 8.38 & 8.69 & 8.63 & 8.53 & 8.60 & 7.32 & 8.27 & 7.72 & 7.64 & 7.69 & 6.85 & 7.47 & 7.25 & 7.17 & 7.23 & 5.23 & 6.72 & 6.70 & 6.60 & 6.67 & $*$ & 6.65 \\
\hline$\overline{T_{2}}$ & 8.73 & & 8.54 & 8.44 & 8.51 & 8.07 & 8.39 & 8.25 & 8.17 & 8.23 & 6.57 & 7.80 & 7.12 & 7.04 & 7.08 & 5.15 & 6.60 & 6.39 & 6.31 & 6.36 & $*$ & 6.35 & 5.89 & 5.81 & 5.87 & $*$ & 5.86 \\
\hline$T_{3}$ & 8.73 & & 6.26 & 6.18 & 6.21 & 5.32 & 5.99 & 5.43 & 5.32 & 5.40 & $*$ & 5.38 & $*$ & $*$ & $*$ & $*$ & $*$ & $*$ & $*$ & $*$ & $*$ & $*$ & $*$ & $*$ & $*$ & $*$ & $*$ \\
\hline Mean & 8.73 & & 7.88 & 7.79 & 7.84 & 7.26 & & 7.44 & 7.34 & 7.41 & 6.94 & & 7.42 & 7.34 & 7.38 & 6.00 & & 6.82 & 6.74 & 6.79 & 5.23 & & 6.29 & 6.20 & 6.27 & $*$ & \\
\hline \multicolumn{2}{|c|}{ Statistics } & \multicolumn{3}{|c|}{ SE.m \pm} & \multicolumn{3}{|c|}{ CD @ P=0.05 } & \multicolumn{2}{|c|}{ SE.m \pm} & \multicolumn{3}{|c|}{ CD @ P=0.05 } & \multicolumn{2}{|c|}{ SE.m \pm} & \multicolumn{3}{|c|}{ CD @ P=0.05 } & \multicolumn{2}{|c|}{ SE.m \pm} & \multicolumn{3}{|c|}{ CD @ P=0.05 } & \multicolumn{2}{|c|}{ SE.m \pm} & \multicolumn{3}{|c|}{$C D @ P=0.05$} \\
\hline \multicolumn{3}{|c|}{$\mathrm{C}$} & \multicolumn{2}{|c|}{0.07} & \multicolumn{3}{|c|}{0.21} & \multicolumn{2}{|c|}{0.07} & \multicolumn{3}{|c|}{0.19} & \multicolumn{2}{|c|}{0.05} & \multicolumn{3}{|c|}{0.16} & 0. & & \multicolumn{3}{|c|}{0.13} & 0. & 04 & \multicolumn{3}{|c|}{0.10} \\
\hline & $\mathbf{T}$ & & 0. & & & 0.18 & & & & & 0.17 & & 0. & & & 0.14 & & 0. & & & 0.11 & & 0. & 03 & & 0.09 & \\
\hline & $\mathrm{C} \times \mathrm{T}$ & & 0. & & & NS & & & & & 0.33 & & 0. & & & 0.27 & & 0. & & & 0.22 & & 0. & 06 & & 0.18 & \\
\hline & $\mathrm{C}_{1}$ & : & Ch & tosan & $(1 \%)$ & & & T & : & $4 \pm 1^{0}$ & & & & & & & $*$ & Decaye & $\mathrm{d}$ arils & & & & & & & & \\
\hline & $\mathrm{C}_{2}$ & : & Alc & e vera & gel (1 & $0 \%)$ & & $\mathrm{T}$ & : & $7 \pm 1^{0} \mathrm{C}$ & & & & & & & & & & & & & & & & & \\
\hline & $\mathrm{C}_{3}$ & : & Ho & ley (1 & $\%)$ & & & T & : & Roon & tempe & rature (2 & $6-29^{0} \mathrm{C}$ & & & & & & & & & & & & & & \\
\hline & $\mathrm{C}_{4}$ & : & $\mathrm{Co}$ & trol ( & In-trea & & & & & & & & & & & & & & & & & & & & & & \\
\hline
\end{tabular}


Fig.1 Effect of different edible coatings and storage temperatures on microbial count (CFU) of arils of pomegranate cv. Bhagwa

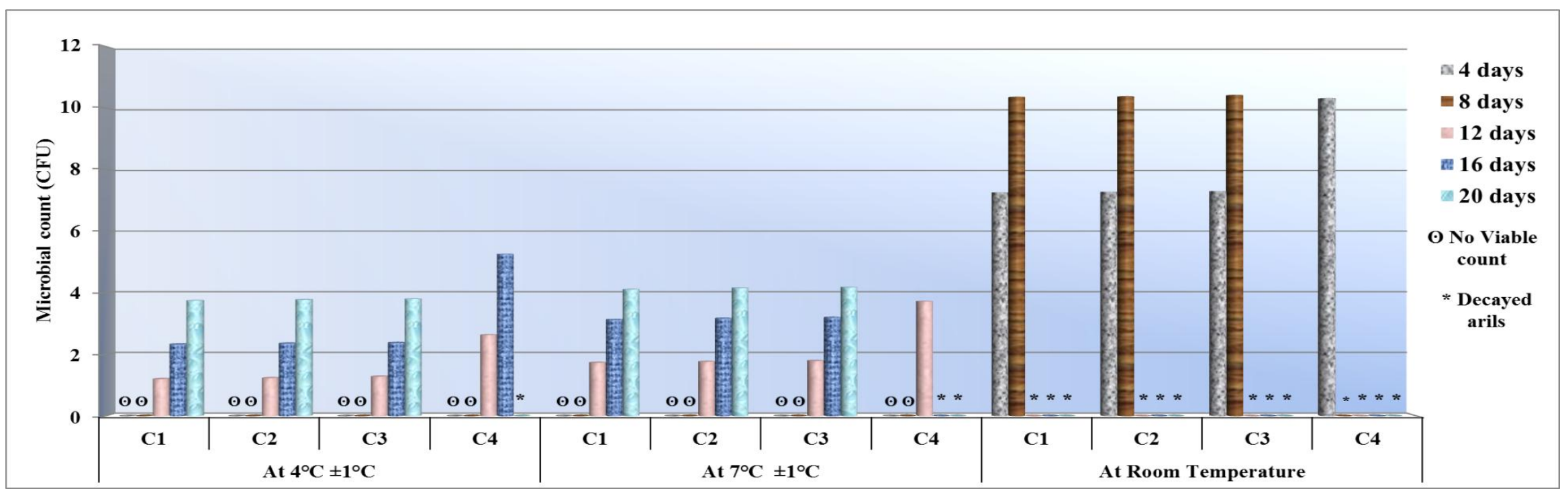

Fig.2 Effect of different edible coatings and storage temperatures on overall acceptability of arils of pomegranate cv. Bhagwa

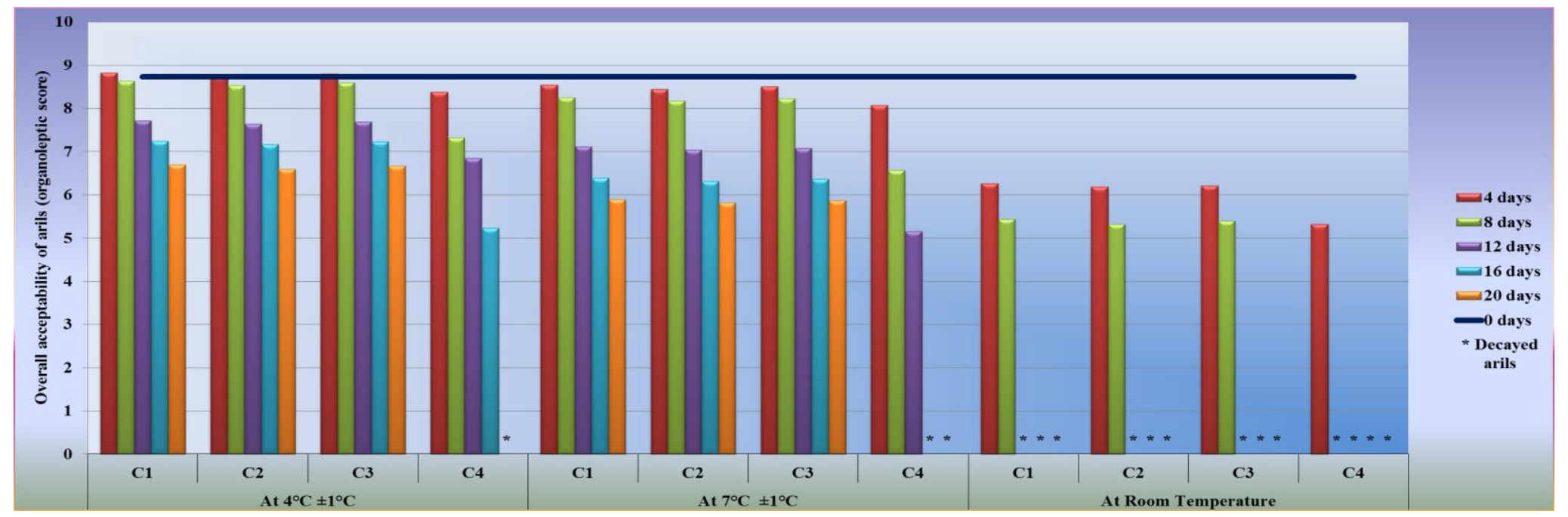


Fig.3 Effect of different edible coatings and storage temperatures on taste of arils of pomegranate cv. Bhawa

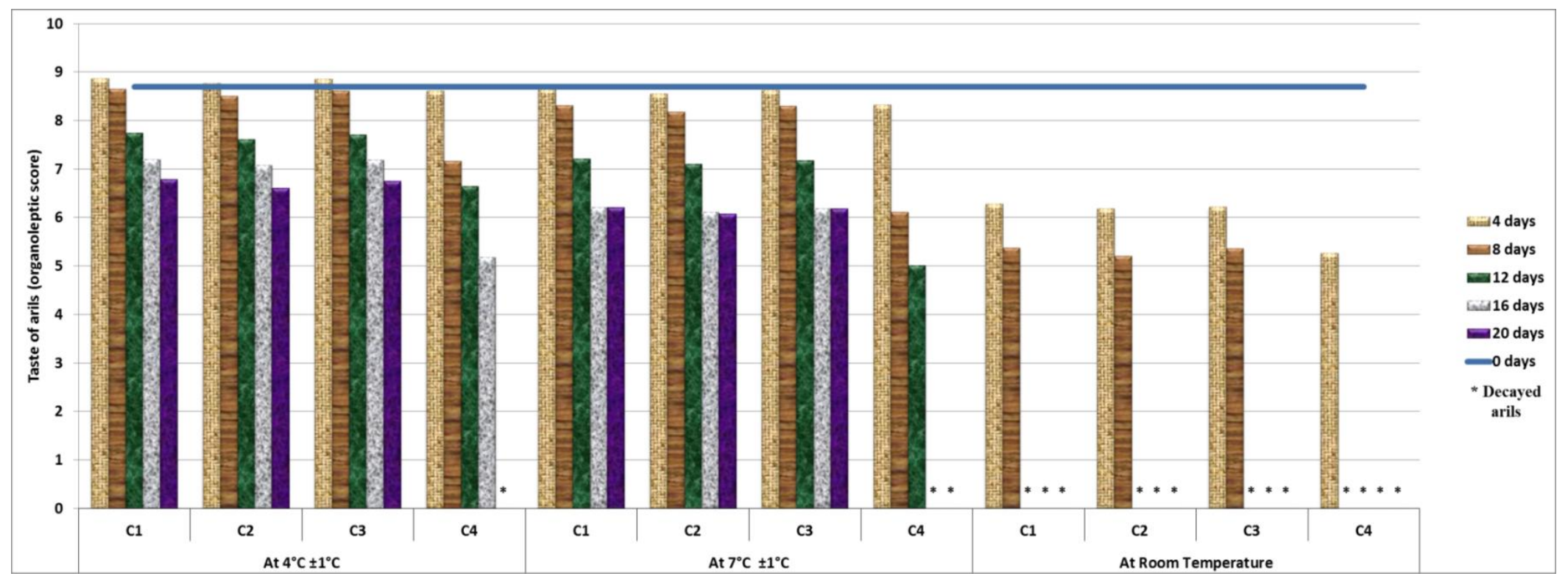

\section{Sensory Evaluation}

\begin{tabular}{|l|l|}
\hline Organoleptic score & Rating \\
\hline 9 & Like extremely \\
\hline 8 & Like very much \\
\hline 7 & Like moderately \\
\hline 6 & Like slightly \\
\hline 5 & Neither like nor dislike \\
\hline 4 & Dislike slightly \\
\hline 3 & Dislike moderately \\
\hline 2 & Dislike very much \\
\hline 1 & Dislike extremely \\
\hline
\end{tabular}

The overall rating was obtained by averaging the score of evaluation. Fruits with sensory score of 5.5 and above were rated as acceptable. 


\section{Overall acceptability of arils}

It is evident from the data presented in (Fig. 2) the organoleptic score for overall acceptability of arils of pomegranate cv. Bhagwa varied significantly owing to the influence of edible coatings and storage temperatures. The highest overall acceptability score of arils was recorded in $\mathrm{C}_{1}$ (1\% chitosan) whereas, lowest overall acceptability score for arils was recorded in $\mathrm{C}_{4}$ (control), with regard to storage temperatures, the overall acceptability score for arils was maximum in $\mathrm{T}_{1}\left(4 \pm 1^{\circ} \mathrm{C}\right)$. The better organoleptic score for pomegranate arils stored at lower temperatures could be attributed to the maximum retention of chemical constituents with proper proportions. Similar observations were also reported by Nanda et al., (2001) in pomegranate and Rathod et al., (2011) in carambola fruits.

Among interaction effects, the maximum overall acceptability score for arils was recorded in $\mathrm{C}_{1} \mathrm{~T}_{1}\left(1 \%\right.$ chitosan and $\left.4 \pm 1^{\circ} \mathrm{C}\right)$ on $4^{\text {th }}(8.83), 8^{\text {th }}(8.63), 12^{\text {th }}(7.72), 16^{\text {th }}(7.25)$ and $20^{\text {th }}$ (6.70) day of storage (Table 2). The minimum overall acceptability score was recorded in $\mathrm{C}_{4} \mathrm{~T}_{3}$ (control and room temperature) (5.32) on $4^{\text {th }}$ day of storage.

Sensory score of 6 and above out of 9 is the limit of acceptance in terms of product attributes such as aril colour, taste, sweetness, texture juiciness and overall acceptability. Organoleptic evaluation of pomegranate arils was carried out by Gill et al., (1996).

The present study revealed that, chitosan (1\%) treated arils with cold storage temperature of $4 \pm 1^{\circ} \mathrm{C}$, was found to be promising against microbial activity and aril decay, with improved quality parameters like taste and overall acceptability during 20 days of storage.

\section{Acknowledgment}

This work was supported by AICRP centre on Arid Zone fruits, Horticulture Research Station, Rekulakunta, Ananthapuramu district, Andhra Pradesh.

\section{References}

Amerine, M.A, Pangborn, R.M. and Rossler, B.B. 1965. Principles of sensory evaluation of food. Academic press, London.

Caleb, O. J, Opara, U. L, Mahajan, P. V, Manley, M, Mokwena, L. and Tredoux, A. G. J. 2013. Effect of modified atmosphere packaging and storage temperature on volatile composition and postharvest life of minimally-processed pomegranate arils (cvs. Acco and Herskawitz). Postharvest Biology and Technology. 79: 54-61.

Chien, P.J, Sheu, F. and Lin, H.R. 2007. Coating citrus (Murcott tangor) fruit with low molecular weight chitosan increases postharvest quality and shelf life. Food Chemistry. 100:1160-1164.

El-Ghaouth, Ponnampalam, A.R, Castaigne, F. and Arul, J. 1992. Chitosan coating to extend the storage life of tomatoes. Horticultural Science. 27: 1016-18.

Eman, Abd, A.A, El-Moneim, Kamel, H.M, Zeinab, Zaki, A. and Abo Rehab, M.E. 2015. Effect of honey and citric acid treatments on post-harvest quality of fruits and fresh-cut of guava. World Journal of Agricultural Sciences. 11(5):255-267.

Gill, M.I, Juan, A, Martinez and Francisco, Artes. 1996. Minimally processed pomegranate seeds. Food Science and Technology Department. 29:708-13.

Heard, G.M. 2002. Microbiology of fresh-cut produce in Fresh-cut fruits and vegetables. CRC Press, Boca Raton. 10: $187-248$. 
Jiang, Y. and Li, Y. 2001. Effect of chitosan coating on post-harvest life and quality of longan fruit. Food Chemistry: 73: 139-143.

Kays, S.J. 1997. Postharvest Physiology of Perishable Plant Products. Vas Nostrand Rein Hold Book, AVI Publishing Co. 147- $316 \mathrm{pp}$.

Lin, L, Wang, B, Wang, M, Cao, J, Zhang, J, $\mathrm{Wu}$, Y. and Jiang, W. 2008. Effects of a chitosan-based coating with ascorbic acid on post-harvest quality and core browning of Yali pears (Pyrus bertschneideri Rehd.). Journal of the Science of Food and Agriculture. 88: 877-884.

Liu, X, Yun, L, Dong, Z, Zhi, L. and Kang D. 2001. Antibacterial action of chitosan and carboxymethylated chitosan. Journal of applied polymers science. 79:1324-1335

Lopez Rubira, V, Conesa, A, Allende, A. and Artes, F. 2005. Shelf-life and overall quality on minimally processed pomegranate arils modified atmosphere packed and treated with UV-C. Postharvest Biology and Technology. 37: 174-185.

Malundo, T.M.M, Baldwin, E.A, Moshonas, M.G, Baker, R.A. and Shewfelt, R.L.
1997. Method for the rapid headspace analysis of mango (Mangifera indica L.) homogenate volatile constituents and factors affecting quantitative results. Journal of Agricultural Food Chemistry. 45(6): 2187-2194.

Munoz, H.P, Almenar, E, Ocio, M.J. and Gavara, R. 2006. Effect of calcium dips and chitosan coating on post-harvest life of strawberries (Fragaria $\times$ ananassa). Postharvest Biology and Technology. 39: 247-253.

Muzzarelli, R.A.A. and Rocchetti, R. 1985. Determination of the degree of acetylation of chitosans by first derivative ultra-violet spectrophotometry. Food Science and Technology Department, 5: 461-72

Nanda, S, Rao, D.V.S, Krishnamurthy, S. 2001. Effects of shrink film wrapping and storage temperature on the shelf life and quality of pomegranate fruits $\mathrm{cv}$. Ganesh. Postharvest Biology and Technology. 22 (1): 61-69.

Rathod, A, Shoba, H. and Chidanand, D.V. 2011. A Study on Shelf life Extension of Carambola Fruits. International Journal of Scientific and Engineering Research. 2 (9): 2229-5518.

\section{How to cite this article:}

Viswanath, M., B. Srinivasulu, K. Swarajya Lakshmi, K. Gopal and Balakrishna, M. 2018. Effect of Edible Coatings and Storage Temperatures on Maintenance of Aril Quality and Microbial Population of Pomegranate cv. Bhagwa Packed in Clamshells. Int.J.Curr.Microbiol.App.Sci. 7(01): 2244-2252. doi: https://doi.org/10.20546/ijcmas.2018.701.271 